\title{
THE EFFECT OF USING BIO-POEM STRATEGY ON STUDENTS' WRITING ABILITY IN DESCRIPTIVE PARAGRAPH
}

\author{
Rizki Amelia \\ State Islamic University of Sultan Syarif Kasim Riau, Indonesia \\ rizki4melia@gmail.com \\ Firza Khaira Maulida \\ State Islamic University Sultan Syarif Kasim of Riau, Indonesia \\ firzapira@gmail.com
}

\begin{abstract}
The aim of this research was to find out whether there was any significant effect of using bio-poem strategy on students' ability in writing descriptive paragraph at Mts Darul Falah Salo Kampar Regency. This research was Experimental Research. The design was quasi-experimental research. The writer formulated the problems that would be answered by using the quantitative research. The subject of the research was the second year students of MTs Darul Falah Salo Kampar Regency academic year 2016/2017. The object of this research was bio poem strategy and their writing ability on descriptive paragraph. The writer took two classes: experimental and control. Experiment class was with 17 students, and control class was with also 17 students. To analyze the data, the writer adopted independent sample T-test formula by using SPSS 20 version. After analyzing the data, the writer found that the students' writing ability was taught by using bio-poem strategy at MTs Darul Falah Salo was categorized into good level. The students' writing ability was taught without using biopoem strategy at MTs Darul Falah Salo was categorized into less level. Writer found that $\mathrm{H}_{\mathrm{a}}$ : sig. $(2$ tailed $)<0.05$. From the research finding it can be concluded that teaching writing by using bio-poem strategy gave large effect on students' writing ability in descriptive paragraph at MTs Darul Falah Salo Kampar Regency.
\end{abstract}

Keyword: Writing Ability, Descriptive Paragraph, Bio-Poem Strategy.

\section{Introduction}

Writing is one of the important skill in learning a language, because it is an important activity to express and convey our ideas, massages, and thoughts in the form of any type in writing, such as letter, memo, poem, short story, and etc. According to Al- jawi (2011:2) writing is a system for thinking processes and interpersonal communication put on paper using visible signs or graphic symbols on a flat surface such as paper, cloth or even stone slabs. Every languages has its own graphic symbols. Furthermore, Patel and Preveen (2008:125) point out 
that writing is essential features of learning a language because it provides a very good means of foxing the vocabulary, spelling and sentence pattern. It becomes an important aspect of students' expression at higher stage.

According to Heaton (1990:135) all of the writing skills are complex and need to be mastered by the students in making a good writing, not only requiring mastery of grammatical and rehetorical devices but also conceptual and judgemental elements. It means that the goal of teaching writing ability should improve students' to be mastered all of the components of writing.

Based on writer observation and interview at Mts Darul Falah Salo Kampar Regency with the English Teacher Dra.Lilis Suryati on May 2016, it was found that English teacher was taught by implementing School Based Curriculum (SBC) and the criteria of students' minimum passing grade (KKM) for English subject is 70. In the curriculum, writing was taught based on standard competence and basic competence of writing.

Regarding with English teacher information that the students of the eight grade still have problems, difficulties and the most of students still had lack vocabulary and could not write in English. Especially in writing descriptive paragraph, the problems faced: Some of the students cannot develop their ideas to write descriptive paragraph well, some of students do not know how to write an identification/ introduction descriptive paragraph, some of students are not able to write descriptive paragraph coherently, some of students are not able to express their description about the topic given, and some of students are not able to implicate simple present tense in a descriptive paragraph. These fact automatically caused them not able to achieve the criteria of students' minimum passing grade. So, writing ability at Mts Darul Falah Salo still far from the expectation of the curriculum.

Based on the writer's preliminary research at MTs Darul Falah Salo at Kampar Regency, the teacher used Three Phase technique. The teacher taught writing through the types of text available in the students textbook. Through the types of the text in their text book, the students recognized and understood about kinds of texts and etc. In teaching descriptive paragraph, the teacher introduced the material to the students and gave an example. After introducing the material, the teacher asked the students to practice writing descriptive paragraph individually. At the end of the learning process, the students submitted their writing.

Regarding to the reasons above, it is necessary for a teacher to use appropriate strategies in teaching writing descriptive paragraph. The writer proposes to use bio-poem strategy in teaching writing descriptive paragraph. Bio-poem strategy are the strategy that describe someone by using a specific format which is organized in several line and in any of the lines there are several ideas that have to be included in.

\section{Review of Related Literature}

\section{Bio-Poem Strategy}

According to Candler (2012:2) a bio-poem is a simple poem written about a person, and it follows a predictable pattern. Bio-poems generally don't rhyme, and they can be autobiographical or biographical. It's best to have students begin by writing Bio-Poems about themselves, but later they can write about famous historical figures or story characters. 
Bio-poems is strategy to learn across the curriculum helps students to think critically and creatively. An excellent strategy to achieve a deeper understanding of a historical figure is a biopoem. A bio-poem "requires students to think carefully about the content of the text and make inferences about what a [historical figure's] actions and statements imply". (Fordham,2002:157).

Hess (2005: 95-96) also point out that, the aim of bio-poem strategy are personal writing and getting to know fellow students. This strategy can used for all levels. The procedures of bio poem strategy are:

a. The teacher together with the class, compose and write on the board a bio-poem of famous person.

Here is the formula for a biopoem:

Line one : First name of person

Line two : Three adjective that describe the person

Line three : Three ing verb that suit the person

Line four : Relative of ...

Line five : Who loves ...

Line six : Who needs ...

Line seven : Who wants ...

Line eight : Who dislike ...

Line nine : Who used to, ...

Line ten : But above all, who ...

Line eleven : Resident of ...

Line twelve : One

complete sentence describe person

Line thirteen : Last

name

b. The teacher asks the students to read own bio-poem to the class.

c. The teacher provide the students in pairs, students interview partners and write bio-poem about them

d. The teacher post the biopoem on the walls of the class.

e. The teacher make a class book of bio-poem.

f. The teacher if possible, provide a book of bio-poems for each students and let the students write massages to one another on the page where the bio-poem appears.

\section{The Advantages of Bio-Poem Strategy}

Sherly and Hafizh (2014:238) point out that, the advantages of bio-poem as follows:

a. Bio-Poem is a strategy that allows the students to think critically about a character.

b. Students are guided by the pattern of bio-poem in order to make us easier in gathering the information of a topic.

c. Help the students in writing because it allows them to express their ideas in pleasure way.

d. Helping the students to organize and generate a lot of ideas to write about an object.

\section{Methodology}

\section{Design of the Research}

The type of this research is experimental research. This research used a quasi-experimental design. Lodico et.al added (2010:24) experimental research is designed to determine cause-effect relationship. It means that in an experimental research, we make some tests after giving treatment to find out how far the influence of our strategy to the students. 
In conducting this research, two classes as sample based on the total sampling. The first class was used as experimental class which was taught by using bio poem strategy. During the treatment to measure the students' ability in writing a descriptive paragraph.

According to Creswell (2008:299) experimental research is used when the writer wants to establish possible cause and effect between the independent and the dependent variables. Then, he (2012:295) stated that, experiment is testing an idea (for practice or procedure) to determine whether it influence an outcome or dependent variable. There were two variables used in this research. The first was using bio-poem strategy (independent variable) symbolized as $(\mathrm{X})$ and the second was students' writing ability (dependent variable) symbolized as (Y). Therefore the experimental and control class will be provided with pre-test, treatment, and post-test.

The population of the research was the eight grade students Mts Darul Falah Salo Kampar Regency. They consisted of two classes. The total number of population was 34 students. The writer used total sampling technique in determining the sample of the research. According to Sugiyono (2015:67) total sampling is a sampling technique when all members of the population used as a sample. This is often done when the population size is relatively small, less than 30 people or research to make generalizations with a very small error. In this research, the writer took the whole of available population as the sample of the research because the number of the population was not so large. Furthermore, those two classes were homogeneous. It was indicated by the same curriculum used by the school for both classes and the students competence in writing skill in which both classes were not different. In this research class VIII $B$ as experimental class, while VIII A as control class.

\section{Technique of Collecting Data}

The writer collect the data by using test. The test was used to find out the students' writing ability. The type of the test was written test related to the topic. To get the data about the students' writing ability, the writer used assessment based on the indicators of writing ability. The aspects that should be measured in writing descriptive paragraph were content, Organization, vocabulary, language feature, and spelling and punctuation.

The writer could make the pre and post test by same materials. Then, the writer gave the test twice, before and after the treatment intended to obtain the students' writing ability of the eight grade students at Mts Darul Falah Salo Kampar Regency.

The test was divided into two test; pre-test and post-test. Pre test was given before treatment. The test was administered to class VIII $\mathrm{B}$ as experimental class and class VIIIA as control class. Post- test was given after teaching several time, it was given for both of the classes. The test was administered to class VIII B as experimental class and class VIIIA as control class.

In order to see whether there was the effect of using bio-poem strategy on students' writing ability, the writer used independent sample t-test Formula trough SPSS 20. and eta squared.

In this research, writer assessed the normality of data by using kolmogorov-smirnov test from SPSS 20 version. It can be concluded that the test distribution is normal. Then, to find out the homogeneity of the test, the writer 
used SPSS 20. In conclusion the data of test was homogenous.

\section{Technique of Analyzing Data}

The data of this research were the scores of students' test of both experiment and control classes. The main purpose of the research was to explore the effect of using bio-poem strategy on students' writing ability. Test from the students' writing ability score were analyzed by using quantitative data analysis for the findings. Both descriptive and inferential statistical analyses were included. Frequency counts, percentages, mean scores and standard deviation of the variables were presented in the descriptive statistical analyses. The hypotheses developed for this study were tested by using an independent sample t-test.

In this research, the data were analyzed by using statistic software of Statistical Product and Service Solutions (SPSS) 20 version. The result of t-test analyzing could be seen on the SPSS output, independent sample t-test and eta squared.

After computing t-test, it was obtained the degree of freedom used to determine whether the t-score was significant or not. The obtained value was consulted with the value of t-table by using degree of freedom (df) = (NI+N2)-2 statically hypothesis Hartono (2004:209). There were two points discussed here; using world cafe strategy (X), and students' writing $\operatorname{ability}(\mathrm{Y})$.

The data of this research were the score of the students' writing ability obtained by written test. The test was given twice to the sample in both experimental class and control class, the first test was pre-test and the second was post-test. Pre-test was done before teaching by using bio-poem strategy and post-test was to know the effect of using bio-poem strategy to get data about students writing ability in descriptive paragraph.

\section{Research Finding}

Students' Ability in Writing Descriptive Paragraph Taught by Using Bio-Poem Strategy

\section{Histogram 1 \\ Histogram of Students' Post Test Scores in Experimental Class}

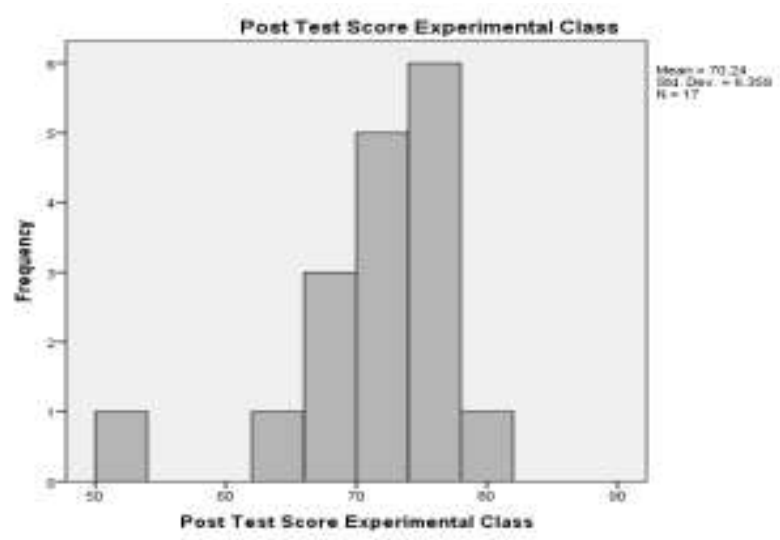


From the histogram above, it shows that the total number of students was 17 students, the mean score of the students was 70,24 , the median was 72,00 , the standard deviation was 6,359 , and the total of the score was 1194 . Next the following paragraph shows the classification of students' score as well to analyze the students post test score in experimental class described as follow:

Table 2

Classification of Students' Scores

\begin{tabular}{ccccc}
\hline No & Score & Categories & Frequency & Percentage \\
\hline $\mathbf{1}$ & $80-100$ & Very Good & 15 & $88,2 \%$ \\
$\mathbf{2}$ & $66-79$ & Good & 1 & $5,9 \%$ \\
$\mathbf{3}$ & $56-65$ & Enough & 1 & $5,9 \%$ \\
$\mathbf{4}$ & $40-55$ & Less & 17 & \\
$\mathbf{5}$ & $30-39$ & Bad & & $100 \%$ \\
& & Total & & \\
\hline
\end{tabular}

(Arikunto, 2009:245)

Based on the table above, there was 1 student got score 40-55 categorized to get Less score ,there was 1 student got score 56-65 and categorized to get Enough score and there were 15 students got score 66-79 and categorized to get good score. Thus, the majority of the students in experimental class was classified into good category.

\section{Students' Ability in Writing Descriptive Paragraph Taught without Using Bio-Poem Strategy}

The data of students' ability in writing descriptive paragraph taught without using bio poem strategy were obtained from the students ${ }^{6}$ post test score in control class.

\section{Histogram 3 \\ Histogram of Students' Post Test Scores in Control Class}

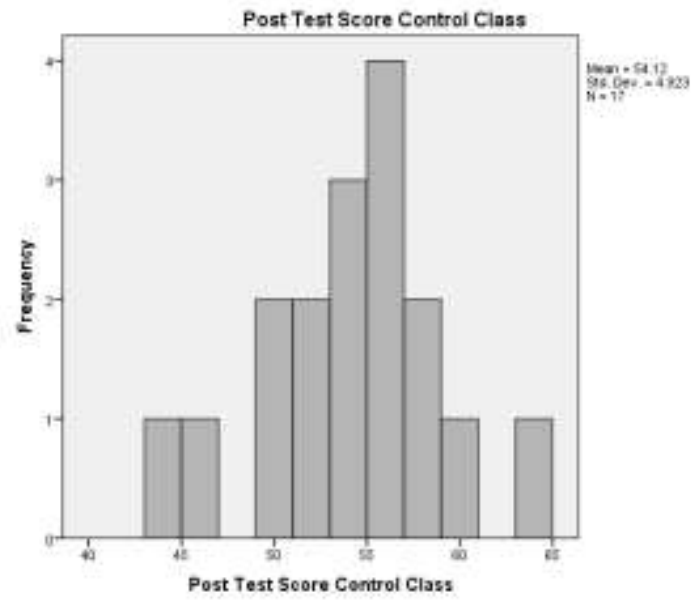


From the histogram above, it shows that the total number of students was 17 students, the mean score of the students was 54,12 , the median was 54,00 , the standard deviation was 4,923 , and the total of the score was 920 . Furthermore, the classification of students' post test score in control class described as follows:

Table 4

Classification of Students' Scores

\begin{tabular}{ccccc}
\hline No & Score & Categories & Frequency & Percentage \\
\hline 1 & $80-100$ & Very Good & & \\
2 & $66-79$ & Good & & \\
3 & $56-65$ & Enough & 8 & $47 \%$ \\
4 & $40-55$ & Less & 9 & $53 \%$ \\
5 & $30-39$ & Bad & & \\
& Total & & 17 & $100 \%$ \\
\hline
\end{tabular}

(Arikunto, 2009:245)

Based on the table above, there were 8 students got score 56-65 and categorized to get Enough score. Then, there were 9 students got score 40-55 and categorized to get Less score. Thus, the majority of the students in control class was classified into Less category.
Significant Difference of Using BioPoem Strategy on Students' Ability in Writing Descriptive Paragraph

The data used to present the significant difference of using bio poem strategy on students' ability in writing descriptive paragraph were obtained from the post test scores of experimental and control classes calculated by using SPSS-20 version. In order to know whether the data used parametric or non parametric analysis, the researcher previously needed to apply normality analysis by using kolmogorov smirnov method in SPSS 20 version. Which was described as follows:

Table 5

Test of Normality

\begin{tabular}{|l|r|r|r|}
\hline \multirow{2}{*}{} & \multicolumn{3}{|c|}{ Kolmogorov-Smirnov $^{\mathrm{a}}$} \\
\cline { 2 - 4 } & Statistic & \multicolumn{1}{c|}{ df } & \multicolumn{1}{c|}{ Sig. } \\
\hline $\begin{array}{l}\text { Post Test Control } \\
\text { Class }\end{array}$ & .138 & 17 & $.200^{*}$ \\
$\begin{array}{l}\text { Post Test Experiment } \\
\text { Class }\end{array}$ & .198 & 17 & .077 \\
\hline
\end{tabular}




\section{Hypothesis :}

Ho (Null Hypothesis): Data is normally Distributed

Ha (Alternative Hypothesis): Data is abnormally Distributed

Testing criteria :

If probably ( $\mathrm{sig})>0.05$, Ho is Accepted

If probably $(\mathrm{sig})<0.05, \mathrm{H}_{\mathrm{o}}$ is Rejected

According to Pallant (2003: 58) If the "Sig" column of either test is higher than 0.05 , the data are normally distributed. From the table IV.15 above, the significant value of post-test experimental and control classes were 0.077 and 0.200 . Because of sig $>0.05$ $(0.077>0.05)$ and $(0.200>0.05)$, the initial data of experimental and control

\section{Table 6}

Test of Homogenity of Variences

\begin{tabular}{|c|c|c|c|}
\hline $\begin{array}{l}\text { Levene } \\
\text { Statistic }\end{array}$ & $\mathrm{df1}$ & $\mathrm{df} 2$ & Sig. \\
\hline .634 & 1 & 32 & .432 \\
\hline
\end{tabular}

Based on the table above , the probability ( sig) was 0.432 . It was higher than $0.05(0.432>0.05)$. It can be concluded that the data was homogen. classes were normally distributed. Therefore, the writer used independent sample T-test.

Furthermore in order to know whether the object writer had the same variance or not, the writer previously described the homogenity analysis as follows: 
Table 8

Independent Sample t-test of Post-Test

in Experimental Class and Control Class

\begin{tabular}{|c|c|c|c|c|c|c|c|c|c|}
\hline & \multicolumn{2}{|c|}{\begin{tabular}{|c|} 
Levene's \\
Test for \\
Equality \\
of \\
Variances \\
\end{tabular}} & \multicolumn{7}{|c|}{ t-test for Equality of Means } \\
\hline & \multirow[t]{2}{*}{$\mathrm{F}$} & \multirow[t]{2}{*}{ Sig. } & \multirow[t]{2}{*}{$\mathrm{T}$} & \multirow[t]{2}{*}{ Df } & \multirow[t]{2}{*}{$\begin{array}{c}\text { Sig. } \\
(2- \\
\text { tailed })\end{array}$} & \multirow[t]{2}{*}{$\begin{array}{c}\text { Mean } \\
\text { Difference }\end{array}$} & \multirow[t]{2}{*}{$\begin{array}{l}\text { Std. Error } \\
\text { Difference }\end{array}$} & \multicolumn{2}{|c|}{$\begin{array}{c}95 \% \\
\text { Confidence } \\
\text { Interval of } \\
\text { the } \\
\text { Difference } \\
\end{array}$} \\
\hline & & & & & & & & Lower & Upper \\
\hline $\begin{array}{ll} & \text { Equal } \\
\text { Score Post } & \text { variances } \\
\text { Test } & \text { assumed } \\
\text { Experiment } & \text { Equal } \\
\text { and } & \text { variances } \\
\text { Control } & \text { not } \\
\text { Class } & \text { assumed }\end{array}$ & .634 & .432 & 8.263 & 30.110 & .000 & 16.118 & 1.951 & $\left|\begin{array}{l}12.145 \\
12.135\end{array}\right|$ & 20.101 \\
\hline
\end{tabular}

After getting the output of SPSS analysis, the writer interpreted the output of independent sample t-test shows that the t-test result is 8,263 its df is 32 , significant is 0,432 , mean difference is 16,118 its standard error is 1,91 lower difference interval is 12 and upper difference interval is 20.

Based on Independent T-test analysis for post-test writing ability on descriptive paragraph score of experimental and control group above, it showed that there is a significant difference at post test writing ability on descriptive paragraph between experimental and control group. T-test result is 8,263 , its df is 32 , standard deviation of experimental group is 6,359 and control group 4,923. So, in the conclusion sig 2-tailed is 0.000 , the 2-tailed value is smaller than 0.05 a. Hypothesis Testing Statistically, the hypotheses are formulated as:

$$
\begin{aligned}
& H_{0}: \text { sig. }(2 \text { tailed })>0.05 \\
& H_{a}: \text { sig. }(2 \text { tailed })<0.05
\end{aligned}
$$

Based on Analysis above, of the first hypothesis $\mathrm{Ha}$ is accepted and $\mathrm{Ho}$ is rejected. So, it can be concluded that "There is a significant difference on students' writing ability descriptive paragraph by using Bio Poem Strategy at Mts Darul Falah Salo Kampar Regency.

\section{Significant Effect of Using Bio-Poem Strategy on Students' Ability in Writing Descriptive Paragraph}

The inferential procedures stated with the statistical test on the following null hypothesis are as follows:

a. $\mathrm{H}_{0}$ : There is no significant effect of using bio poem strategy on students' writing 
ability in descriptive paragraph at Mts Darul Falah Salo of Kampar Regency.

b. Ha: There is a significant effect of using bio poem strategy on students' writing ability in descriptive paragraph at Mts Darul Falah Salo of Kampar Regency.

To identify the level of effect of using bio poem strategy on students' ability in writing descriptive paragraph at Mts Darul Falah Kampar Regency, The writer used Eta Sequared Formula as Follows :

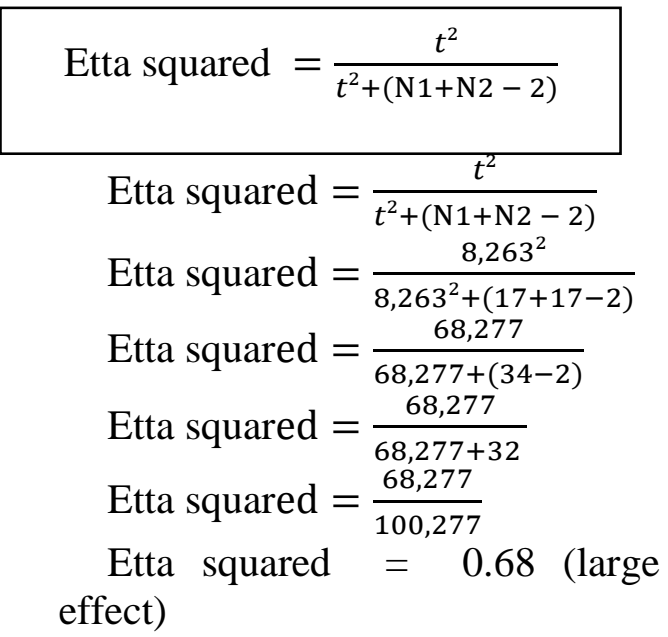

According to Cohen (1988 in pallant, (2003:181). The guidelines for interpreting the value of etta square are as follow:

Table IV.18

Effect Size Guidelines

\begin{tabular}{|l|}
\hline $0,01=$ Small Effect \\
\hline $0,06=$ Moderate Effect \\
\hline $0,14=$ Large Effect \\
\hline
\end{tabular}

Based on the calculation above, eta square was 0,68 referering to the table of effect size guidelines above, 0,68 was larger than 0,14 . Thus the effect size was categorized as large effect.

To find out the percentage of effect, the writer used the following formula is used:

$$
\begin{aligned}
& ={ }^{n 2} \text { X 100\% } \\
& =0.68 \times 100 \% \\
& =68 \%
\end{aligned}
$$

Based on the data analysis about students' ability in writing descriptive paragraph, it showed that mean of the students' writing ability taught by using bio-poem strategy in the experimental class was higher than mean of the students' writing ability taught without using bio-poem strategy in control class.
It can be concluded that teaching writing by using bio-poem strategy had large effect on students writing ability. Thus there is significant effect of teaching English by using bio poem strategy on the eight grade students' ability in writing narrative text at Mts Darul Falah Salo Kampar Regency.

\section{Disscussion}

Based on the research finding, the writer concludes that the students' writing ability was taught by using BioPoem strategy at the eight grade students Mts Darul Falah Salo was categorized into good level. The students' writing ability was taught without using Bio Poem strategy at the eight grade students Mts Darul Falah Salo was categorized into Less level, 
and there was a significant effect of using Bio-Poem strategy on students' writing ability at eight grade students Mts Darul Falah Salo Kampar Regency.

\section{Conclusion}

Based on finding as already discussed before, it can be conclude that in teaching writing by using bio-poem strategy of the eight grade at Mts Darul Falah Salo KamparRegency is better than without using bio-poem strategy.

\section{Bibliography}

Al jawi,Fadwa Dawood. 2011. Teaching the Productive Skill in EFL Teaching EFL Writing.https://old.uqu.edu.sa/fi les2/tiny_mce/plugins/filemana ger/files/4281126/lectures_of Methodology_2/the_writing_Sk ills_wtihout_protection.pdf Retrieved on May 17,2016

Candler, Laura. 2012. Bio Poems MadeEasy.http://www.pawnee schools.com/vimages/shared/v news/stories/4e61914de4269/F REEBioPoemsMadeEasy.pdf retrieved on May 10, 2016

Creswell, J. 2012. Educational Research Planning, Conducting and Evaluating Quantitative and Qualitative Research. (P. Smith, Ed.) (fourthedi., p. 295). Boston: Pearsin Education, Inc.

Deswita, Sherly and Hafizh, Muhd. 2014. Teaching Writing A Descriptive Text by using Bio Poem Strategy to Junior High School Students. JELT.Vol.2 No.2 Serie C (journal)
Thus, there is a significant effect of teaching writing descriptive paragraph by using bio-poem strategy on the eight grade students at Mts Darul Falah Salo Kampar Regency.

Bio-poem strategy is expected can give valuable reference for the next writer who are interested in carrying out a research in similar discussion topic. The writer also expects that this thesis can be used for the next researchers who carry out an experimental research.

Retrieved on May 07,2016

Hartono. 2015. Statistik Untuk Penelitian. Yogyakarta: PustakaPelajar

Heaton, J.B.1990. Writing English Language Test. New York: Longman Group

Hess,Natalie.2005. Teaching Large Multilevel Classes. Cambridge: Cambridge University Press

Pallant, J. 2005. SPSS Survival Manual. Chicago: Allen and Unwin

Pater,M.E and Preveen M.Jain.2008. English Language Teaching (Method, Toolsand Techniques). Jaipur: Sunrise publisher

Standar Isi Untuk Satuan Pendidikan Dasar dan Menengah: Standar Kopetensi dan Kopetensi Dasar SMP/MTS. (Jakarta: Badan Standar Nasional Pendidikan (BNSP, 2006).

Sugiyono, Prof, Dr. 2015. Metode Penelitian Pendidikan. Bandung: Alfabeta. 